\title{
Research on the Feasibility of Copying the Tax Policy of Shanghai FTA to Promote the Development of border Trade: Take Heilongjiang Province, China as an example*
}

\author{
Shu-Feng Wang \\ Accounting Institute, Heilongjiang Bayi Agricultural University \\ Daqing City, 163319, China \\ Wsf630817@163.com, \\ Hong-Yan Tang \\ Graduate School of 2015 master of accounting, \\ Heilongjiang Bayi Agricultural University \\ Daqing City, 163319, China \\ 1758136249@qq.com
}

\begin{abstract}
Combined with the Heilongiiang economic and trade development is particularly urgent requirement to build regional free trade zone border, by analogy analysis, judgment and reasoning methods, analysis of Heilongjiang Province trade development problems and cause, tax policy and the characteristics of Shanghai FTA are reviewed. And from the trade environment demand, trade location adaptability, economic development of domestic power and related policy supporting mechanism sound level, demonstrates the feasibility of Heilongiiang province Shanghai FTA copy tax policy.
\end{abstract}

Keywords: Heilongjiang province; Shanghai FTA; tax policy.

\section{Introduction}

In recent years, Heilongjiang Province the promotion of economic growth as an important engine of trade, it did not play its due role [1]. To break the impasse in Heilongjiang economic development, to be multi-faceted thinking, to explore a new path, the tax policies and systems of Shanghai since the establishment of the FTA implementation achieved fruitful results, according to the central deployment, Shanghai FTA tax policy system can copy within built nationwide promotion mode, which will promote the development of the wave of a new

\footnotetext{
* The research and publication, thanks to The economic and social development in Heilongjiang province key research project "Research on the tax policy in Heilongjiang Province copied Shanghai FTA (15048)" of the support fund..In the completion of the project process, Heilongjiang Provincial Leading Group for the reform of the Finance Office of the enthusiastic guidance and support. Here, to express my sincere gratitude!
} 
round of trade, but also to copy the country's tax policy experiences of Shanghai FTA to promote trade and economic revitalization of Heilongjiang Province which have a long border line and the level of trade has been lagging behind other parts of the country, pointed out the direction.

\section{The Objective Needs of Tax Policy to the Trade and Economic Development Of Heilongjiang Province}

\subsection{The trade analysis of Heilongjiang Province}

\subsubsection{Growth stalled}

Heilongjiang Provincial Foreign Trade developed rapidly between 2006 and 2010, during which only in 2008 declined due to the impact of the economic crisis, the rest of the year increased significantly, from $\$ 12.86$ billion trade volume in 2010 increased to $\$ 25.5$ billion, an increase of nearly $100 \%$, average annual growth of nearly $20 \%$. But after 2011 , it has gradually stagnated; it has traded over a hundred million in 2014 with 39 countries (regions), which accounted for about $60 \%$ of Russian trade. The province's import and export value $\$ 38.9$ billion, an increase of $0.1 \%$ over the previous year, while import and export of border trade was only $\$ 9.12$ billion which was the end level in the country, has been down $3.8 \%$. As shown in Table 1:

Table 1 National and foreign trade data of Heilongjiang Province

\begin{tabular}{c|cc|ccc}
\hline \multirow{2}{*}{ Year } & \multicolumn{2}{|c|}{ Entire Country } & \multicolumn{3}{c}{ Heilongjiang Province } \\
\cline { 2 - 6 } & $\begin{array}{c}\text { Trade volume } \\
\text { (US \$ billion) }\end{array}$ & $\begin{array}{c}\text { Growth } \\
(\%)\end{array}$ & $\begin{array}{c}\text { Trade volume } \\
\text { (US \$ billion) }\end{array}$ & $\begin{array}{c}\text { Growth } \\
(\%)\end{array}$ & $\begin{array}{c}\text { Accounting for the } \\
\text { proportion (\%) }\end{array}$ \\
\hline 2011 & 36419 & 22.46 & 385 & 50.98 & 1.05 \\
2012 & 38671 & 6.18 & 378 & -1.81 & 0.97 \\
2013 & 41590 & 7.55 & 388.7 & 2.65 & 0.93 \\
2014 & 43030 & 3.46 & 389 & 0.1 & 0.9 \\
\hline
\end{tabular}

As can be seen from the table, it had explosive growth since only 2011 over the previous year when coming into the "Twelve Five", the rest of the year was almost stagnant until 2014, total trade grew by only $1.04 \%$ over 2011, the growth rate declined obvious. While the national growth rate over the same period although the volume of trade was slowing down, but the total also increased by $18 \%$, an average annual increase of nearly $6 \%$. As a border province, the country's total trade volume of trade was only $0.9 \%$, accounting for the province's GDP (2447 billion) share of $15.5 \%$, which was clearly 
inconsistent with its border province status.

\subsubsection{Significantly dependent on trade with Russia}

After continuous foreign development of Heilongjiang Province, the existing trading partner for almost more than 40 countries and regions, but a large trade gap between the trade partners, the province's trade volume in Russia has always played a large proportion of trade, as shown in Table 2 as follows:

Table 2 2011-2014 in Heilongjiang Province trade data for Russia

\begin{tabular}{c|c|ccc}
\hline \multirow{2}{*}{ Year } & Entire Country & \multicolumn{3}{|c}{ Heilongjiang Province } \\
\cline { 2 - 5 } & $\begin{array}{c}\text { Russia trade } \\
\text { volume (US } \\
\text { \$ billion) }\end{array}$ & $\begin{array}{c}\text { Russia trade } \\
\text { volume (US } \\
\text { \$ billion) }\end{array}$ & $\begin{array}{c}\text { Accounting for the } \\
\text { proportion of the } \\
\text { province's trade (\%) }\end{array}$ & $\begin{array}{c}\text { The proportion of the } \\
\text { country's total trade with } \\
\text { Russia (\%) }\end{array}$ \\
\hline 2011 & 792.7 & 189.9 & 49.32 & 23.96 \\
2012 & 882.1 & 213.1 & 56.35 & 24.16 \\
2013 & 892.6 & 223.6 & 57.53 & 25.05 \\
2014 & 952.8 & 232.8 & 59.85 & 24.43 \\
\hline
\end{tabular}

Obviously, during the "Twelve Five "period the proportion of trade with Russia in Heilongjiang was gradually climb to close to $60 \%$ in 2014 , according to statistics from the second object as the province's trade ASEAN trade in 2014 was only $\$ 2.36$ billion, a considerable $1 / 10$ on trade with Russia, we can see that foreign trade in Heilongjiang province's dependence on Russia is obvious. Meanwhile Heilongjiang Province and Russia's business in recent years has accounted for an important position in the country trade with Russia; the base occupies a quarter of the country's trade with Russia.

\subsection{Trade Development disadvantage reverse tax policies need specialized support}

Tax policy is not only to support the dominant elements of regional trade and economic development, but also is the urgent needs of severe economic backwardness in Heilongjiang Province trade under conditions. Over the years, Heilongjiang Province, as an important old industrial base in the northeast, in addition to the State for the northeast old industrial base introduction of the relevant tax policies, there aren't any specific policies to promote the development of border trade. While the northeast old industrial base of tax policy, were directed against the equipment manufacturing industry, petrochemical industry, metallurgical industry, shipbuilding, automobile 
manufacturing, high-tech industry, military industry and agro-industry and other eight manufacturing industries, mainly to take the newly purchased fixed Assets can deduct input VAT "consumption VAT" policy, according to fixed assets and intangible assets does not exceed a specified minimum number of years of $40 \%$ margin shorten the depreciation or amortization period. But with the 2009 implementation of the new VAT law, as well as shorten the depreciation period of fixed assets or accelerated depreciation of taxation (2014) No. 75, the State Administration of Taxation Announcement No. 68 in 2015 and taxation (2015) No. 106 and other relevant policies, there are no longer basically exclusive tax incentives to Northeast Old industrial enterprises. Seen from that the current trade development in Heilongjiang Province has no special tax incentives, border trade also operate within the framework of a unified national basic tax.

Shanghai Free Trade Zone and the rapid development of the rapid completion of successful experience shows that investment stimulating effect of special tax policy strong, huge capital accumulation function. Heilongjiang Province as resources in the province, the country has contributed almost all of the underground mineral and forest resources in the ground is the most important strategic grain reserve supply provinces. Heilongjiang Province, the attractive of the existing policy system of capital and technology that want to come into the trade area is still underdevelopment, participation in trade are mostly small and medium private enterprises, there is no cross-border operations have the ability to market players, to solve these problems and promote the rapid development of trade in Heilongjiang Province, and regard Shanghai Free Trade zone as an opportunity to study the formation of tax policy to replicate its strong policy guidance and support, is very suitable for a breakthrough.

\section{Copy the Shanghai Trade Development Heilongjiang Province FTA feasibility Analysis Tax System}

\subsection{Shanghai Free Trade Zone Tax Policy and Characteristics}

Shanghai FTZ tax policy mainly in three main: areas of investment, trade, equity incentives. These policies did play a good guide. Investment, trade, talent is the three major driving forces of promote regional economic development. Shanghai free trade area aimed at the birth of these three major driving forces tax policies to establish tax electronic network platform as the core, by building industry to attract foreign investment, the introduction of international advanced production equipment, retain top talent-related tax incentives system, the tax revenue to local economic macro-control. Thus, for the provinces and regions to develop local sustainable economic development pointed out the policy course, but also to promote the high degree of integration with the national economy tax 
set an example.

The new policy emphasizes the guiding function, through this guiding function, encourage new capital, new technologies, new talents in the field of economic development, so that the economic structure and continue on the upgrading of the quality. FTA as a testing ground for institutional innovation, which aims to form a copy, replicable experience, will release bonus system expanded to the whole country [2], which is the establishment of a free trade area as a national leader of the fundamental significance of deepening the reform and also with tax policy to promote local trade as an important engine for economic development. Therefore, the state requires of Shanghai FTA tax policy in the country that should have the foundation for the development of trade provinces have replicated the effects.

\subsection{Feasibility of Heilongjiang Province copied Shanghai FTA policy}

\subsubsection{Basis of objective needs favorable environment for trade development}

Good trading environment for the development needs of the FTA is to copy the Shanghai tax policy basic premise. Heilongjiang Province and Russia border, stretches 3,038 kilometers of border line, where the border river (lake) $2300 \mathrm{~km}$, with the advantage of a long border and bilateral friendly relations, border trade is very active and has a long history of trade development. Since the beginning of the last century, 80 years of reform and opening up, took the lead in opening up Suifenhe Russian border crossings, and then another on the adjacent countries to open Heihe, Jiayin, Luobei, Dongning, Mishan, Jiamusi, Tongjiang, Raohe, Hulin , Fujin, Xunke, Huma, Sun Wu, Suibin, Fuyuan, huachuan, Qiqihar, Harbin water transport, aviation Harbin, Harbin Railway freight and Daxing'anling a total of 25 trading ports, of which 17 have already become a tourist port. These ports covered dry ports, water port and airport of the three categories. As of 2014, the Sino-Russian border region of the State Council approved the establishment of the Sino-Russian border trade zones10 in Heilongjiang province, the Russian first class port 15. Lingering border line and continue the revitalization of old industrial bases in the economic situation, Heilongjiang develop border trade provides a huge space, but also the urgent need to copy Shanghai accelerate FTA tax policy to attract investment, the development of free trade and the implementation of equity incentive.

\subsubsection{Strong demand tax policy support for trade economic development}

Admittedly, the Trade Development Heilongjiang hesitant economic important disease is mainly because of the extremely backward. Heilongjiang has great 
potential for the development of border trade, and tax policy that is the reality of economic development, "urging force is." The past two years of economic development of Heilongjiang fully behind the national average, in 2014 economic growth was only $5.6 \%$, while the first half of 2015 is down to $5.1 \%$, ranked third lowest in the country, of which the trade development of backward speech difficult blame, this grim reality makes Heilongjiang province must find a new path of development to promote economic growth. As a traditional economic province, Heilongiiang Province has a good economic base, especially in agriculture and traditional industries, has been a national leader, but with the level of awareness and management behind, structure and institutional deficiencies increasingly apparent,it needs to start from the system and management to institutional innovation as a guide, to attract new capital, new technology and new talent into the field of economic development, optimize the industrial structure, let economy back on a path of healthy and rapid development, Shanghai FTA successful experience is gained, so Heilongjiang saw the light and has an urgent need for the experience to lead the reform.

\subsubsection{Location advantages create a FTZ is to copy foothold System}

As a border province, Heilongjiang has a large number of Russian trade port, with this advantage, it can carry out content-rich border trade and constantly improve the business level, the establishment of mutually beneficial and win-win regional economic union, to promote industrial restructuring. Current Heilongjiang Russian trade is still in the lower level, with a very large space for development, and therefore it is imperative to actively explore the establishment of a free trade zone along the border, the border trade zone adopted a special tax policy [3], in order to promote healthy and rapid development of trade. At this copy of the tax policy Shanghai FTA can do the job more efficiently, thereby allowing more money and technology into the field of trade, the formation of a number of multinational enterprises operating capabilities, and as a guide, promote province within the enterprise to carry out industrial restructuring, transformation from primary products processing to high-end manufacturing, and constantly improve the trade product structure, improve the trade level, and ultimately enhance the level of trade with Russia, based on trade to vigorously carry out other countries, the real trade has become an important engine of economic development of Heilongjiang.

\subsubsection{Policy system has a sound tax policy convergence and replication}

As early as 2003 ,The state developed a strategy to revitalize the old northeast industrial base, which provides a guarantee for fast economic growth in 
Heilongjiang province in the next few years, the country has continued to date improve the strategy to revitalize the economy in northeast. In March 2015 the State Council issued the "push to build a 21st century Silk Road economic belt and the Maritime Silk Road vision and action", also made very clear role for Russia and Heilongjiang Province in Northeast Asia Open Process .On January 29,2015, the State Council issued the "State Council on the promotion of China (Shanghai) free trade zone can be replicated test pilot reform experience," which clearly pointed out that the experience and achievements of Shanghai FTA in deepening reform and institutional innovation, should be replicated across the country, which undoubtedly Heilongjiang Province copy FTA tax policy in trade development provides policy convergence, thereby forming a tax policy supporting the implementation of the mutual guarantee system.

\section{Conclusion}

Heilongjiang province economy has a good foundation and an excellent location, while economic development is urgently needed the strong support of the central policy, it can be said everything is ready only a strong wind, Shanghai FTA makes tax policy can be copied Trade Development Heilongjiang clear policy direction, especially Shanghai FTA asset restructuring tax policy model will be promoting the Heilongjiang Province and Russia's business circles to build in key application target [4]. Of course, the policy is not a simple copy ism, be combined with the actual situation of the development of practical policies. This requires Heilongjiang fiscal and trade development should be combined with the two-way relationship to the needs and possibilities for the future of the province's business development planning, in-depth feasibility studies and local tax incentives to support business development for national tax policy to support the formation of a free trade zone in Shanghai Tax Policy based on specific copy mode, and seriously address the implementation of tax policy implementation issues, thereby promoting Heilongjiang trade to a higher level of development.

\section{References}

1. Bian Jilan Empirical Study of Heilongjiang Province Export Trade on Economic Growth [J] business economy, 2008 eleventh sixth pages. In Chinese.

2. ChenShaoying, LuChenggang construction and innovation of China (Shanghai) free trade area of tax law system test $[\mathrm{J}]$ Shanghai Business College, In 2013 twelfth, pp. 10-14. In Chinese

3. SuRufei. Policy Research Tax promote border trade development [J] Local Fiscal Studies, Fifth 2015, pp. 69-74. In Chinese 
4. TangYaqi, GaoXiang, WangJinging new solutions Shanghai FTA tax policies [J] accounting communications, Twenty-eighth 2014, pp. 67-69. In Chinese 